13,12

\title{
Плотность и размер частиц нанокристаллических порошков кубического карбида ниобия $\mathrm{NbC}_{y}$
}

\author{
(C) А.С. Курлов, А.И. Гусев \\ Институт химии твердого тела УрО РАН, \\ Екатеринбург, Россия \\ ฯ E-mail: gusev@ihim.uran.ru \\ (Поступила в Редакцию 12 мая 2016 г.)
}

Методом гелиевой пикнометрии измерена плотность крупнокристаллических (со средним размером частиц 3-5мкм) и нанокристаллических порошков карбида ниобия $\mathrm{NbC}_{y}(0.77 \leq y \leq 0.96)$ с разным средним размером частиц от 60 до $30 \mathrm{~nm}$. Нанопорошки получены высокоэнергетическим размолом исходных крупнокристаллических порошков карбида ниобия. Размер частиц в порошках карбида ниобия оценен методами рентгеновской дифракции и Брунауэра-Эммета-Тейлора. Показано, что плотность нанопорошков, измеренная методом гелиевой пикнометрии, занижена по сравнению с истинной плотностью вследствие адсорбции гелия высокоразвитой поверхностью карбидных нанопорошков.

DOI: 10.21883/FTT.2017.01.43971.182

\section{1. Введение}

В последнее время развиваются методы получения веществ и материалов в нанокристаллическом состоянии. Это связано с модификацией свойств твердых веществ при уменьшении размера кристаллитов (частиц) до 20-30 nm и менее [1,2]. Эффективным методом получения нанокристаллических порошков является высокоэнергетический размол (high-energy ball milling), относящийся к нанотехнологиям группы „сверху-вниз“ (top-down) [3]. Размол широко используется для получения нанопорошков карбидов переходных металлов IV-VI групп [4-6], являющихся наиболее твердыми из известных веществ.

Карбид ниобия $\mathrm{NbC}_{y}$ с кубической (пр.гр. $F m \overline{3} m$ ) структурой $B 1$ обладает широкой областью гомогенности от $\mathrm{NbC}_{0.72}$ до $\mathrm{NbC}_{1.00}$ [7] и входит в группу сильно нестехиометрических соединений. В последние два года авторами настоящей работы выполнена серия исследований микроструктуры наноразмерных порошков карбида ниобия [8-12] в зависимости от нестехиометрии, степени гомогенности, малого размера частиц, микродеформаций, анизотропии решеточных искажений.

В настоящей работе впервые обсуждается влияние нестехиометрии и размера частиц на измеряемую плотность порошков карбида ниобия с учетом площади их удельной поверхности.

\section{2. Образцы и экспериментальные методы}

Крупнокристаллические порошки кубических (пр.гр. $F m \overline{3} m)$ карбидов $\mathrm{NbC}_{0.77}, \mathrm{NbC}_{0.84}, \mathrm{NbC}_{0.93}$ и $\mathrm{NbC}_{0.96}$ со структурой $B 1$ были синтезированы высокотемпературным твердофазным вакуумным спеканием [7] авторами работы [13] по запатентованной методике [14]. Порошки содержат как крупные частицы размером до 4-6 $\mu \mathrm{m}$, так и мелкие частицы размером $500 \mathrm{~nm}$ и менее. Однако мелкие частицы связаны между собой и образуют большие разветвленные агломераты размером до 2-5 $\mu \mathrm{m}$.

Нанокристаллические порошки карбида $\mathrm{NbC}_{y}$ получили размолом исходных крупнокристаллических порошков в планетарной шаровой мельнице PM-200 Retsch. Мелющие шары и футеровка размольных стаканов изготовлены из твердого сплава WC - 6 wt.\% Co. Во всех экспериментах масса $m$ порошка, взятого для размола, составляла $10 \mathrm{~g}$; объем изопропилового спирта, добавляемого при размоле, составлял $15 \mathrm{ml}$. Методика размола описана в работах $[5,6,15,16]$. Энергия $E_{\text {mill }}$, затраченная на размол в течение 5,10 и $15 \mathrm{~h}$, равна 14.1 , 28.1 и $42.2 \mathrm{~kJ}[17,18]$. Удельная энергия размола, отнесенная на $1 \mathrm{~mol}$ карбида ниобия $\mathrm{NbC}_{y}$ с молекулярной массой $M$, равна $E_{\mathrm{sp}-\text { moll }}^{\mathrm{mol}}=E_{\text {mill }} \times(M / m)$ и для карбидов, размолотых в течение 5,10 и $15 \mathrm{~h}$, составляет от $\sim 144$ до $\sim 441 \mathrm{~kJ} \cdot \mathrm{mol}^{-1}$ (см. таблицу).

Кристаллическую структуру и фазовый состав нестехиометрических карбидов ниобия определяли методом рентгеновской дифракции на дифрактометре Shimadzu XRD-7000 методом Брэгга-Брентано в интервале углов $2 \theta$ от 10 до $140^{\circ}$ с пошаговым сканированием $\Delta(2 \theta)=0.03^{\circ}$ и временем экспозиции $2 \mathrm{sec}$ в точке в излучении $\mathrm{Cu} K \alpha_{1,2}$. Рентгенограммы численно анализировали с помощью программного пакета X'Pert Plus [19]. Средний размер $D$ областей когерентного рассеяния в первом приближении рассматривали как средний размер малых частиц и определяли по уширению дифракционных отражений в соответствии с методикой $[5,6,20]$. Дифракционные отражения описывали функцией псевдоФойгта.

Морфологию и размер частиц исходных и размолотых порошков $\mathrm{NbC}_{y}$ изучали на сканирующем электронном микроскопе JEOL JSM 6390 LA. 
Влияние продолжительности $t$ и энергии $E_{\mathrm{sp}-\text { mill }}^{\mathrm{mol}}$ размола на период решетки $a_{B 1}$, площадь удельной поверхности $S_{\mathrm{sp}}$, средний размер частиц $D$ и плотность $\rho$ порошков $\mathrm{NbC}_{y}$

\begin{tabular}{|c|c|c|c|c|c|c|c|c|c|c|}
\hline \multirow{2}{*}{$\mathrm{NbC}_{y}$} & \multirow{2}{*}{$t, \mathrm{~h}$} & \multirow{2}{*}{$\begin{array}{c}E_{\mathrm{sp}-\mathrm{mill}}^{\mathrm{mol}}, \\
\mathrm{kJ} \cdot \mathrm{mol}^{-1}\end{array}$} & \multirow{2}{*}{$\begin{array}{c}a_{B 1} \pm 0.00005 \\
\mathrm{~nm}\end{array}$} & \multirow{2}{*}{$\begin{array}{l}S_{\mathrm{sp}} \pm 20 \\
\mathrm{~m}^{2} \cdot \mathrm{g}^{-1}\end{array}$} & \multicolumn{2}{|c|}{$D \pm 5, \mathrm{~nm}$} & \multicolumn{3}{|c|}{$\rho, \mathrm{g} \cdot \mathrm{cm}^{-3}$} & \multirow{2}{*}{$\begin{array}{c}\Delta \rho=\rho_{X}-\rho_{\mathrm{pHe}} \pm 0.03 \\
\mathrm{~g} \cdot \mathrm{cm}^{-3}\end{array}$} \\
\hline & & & & & БЭТ & рентген & $\rho_{X} \pm 0.01$ & $\rho_{\mathrm{pHe}} \pm 0.01$ & $\rho_{\mathrm{pl}} \pm 0.01$ & \\
\hline \multirow[t]{4}{*}{$\mathrm{NbC}_{0.77}$} & 0 & 0 & 0.44373 & 0.282 & 2730 & - & 7.77 & - & - & - \\
\hline & 5 & 144 & 0.44352 & 12.435 & 62 & 48 & 7.76 & 7.41 & 7.51 & 0.25 \\
\hline & 10 & 287 & 0.44350 & 18.003 & 43 & 41 & 7.78 & 6.95 & 6.85 & 0.83 \\
\hline & 15 & 431 & 0.44351 & 21.144 & 36 & 23 & 7.78 & 6.67 & 6.69 & 1.11 \\
\hline \multirow[t]{4}{*}{$\mathrm{NbC}_{0.84}$} & 0 & 0 & 0.44596 & 0.155 & 4950 & - & 7.71 & 7.69 & 7.70 & 0.02 \\
\hline & 5 & 145 & 0.44561 & 13.742 & 56 & 48 & 7.73 & 7.02 & 6.95 & 0.71 \\
\hline & 10 & 289 & 0.44536 & 20.041 & 38 & 50 & 7.74 & 6.60 & 6.58 & 1.14 \\
\hline & 15 & 433 & 0.44523 & 23.657 & 32 & 28 & 7.75 & 6.32 & 6.28 & 1.43 \\
\hline \multirow[t]{4}{*}{$\mathrm{NbC}_{0.93}$} & 0 & 0 & 0.44667 & 1.190 & 645 & - & 7.76 & 7.70 & 7.81 & 0.06 \\
\hline & 5 & 147 & 0.44645 & 14.485 & 53 & 43 & 7.77 & 7.23 & 7.41 & 0.54 \\
\hline & 10 & 292 & 0.44629 & 18.861 & 41 & 44 & 7.78 & 6.78 & 6.76 & 1.00 \\
\hline & 15 & 439 & 0.44601 & 26.650 & 29 & 30 & 7.79 & 6.05 & 6.03 & 1.74 \\
\hline \multirow[t]{4}{*}{$\mathrm{NbC}_{0.96}$} & 0 & 0 & 0.44675 & 0.230 & 3340 & - & 7.78 & 7.73 & 7.80 & 0.05 \\
\hline & 5 & 147 & 0.44635 & 14.216 & 54 & 64 & 7.81 & 6.86 & 6.97 & 0.95 \\
\hline & 10 & 293 & 0.44612 & 20.484 & 37 & 31 & 7.80 & 6.45 & 6.46 & 1.35 \\
\hline & 15 & 441 & 0.44602 & 24.962 & 31 & 22 & 7.82 & 6.19 & 6.12 & 1.63 \\
\hline
\end{tabular}

Удельную поверхность $\mathrm{S}_{\mathrm{sp}}$ исходных карбидных порошков и тех же порошков после размола определяли методом Брунауэра-Эммета-Тейлора (БЭТ) по изотермам низкотемпературной сорбции паров молекулярного азота при температуре $77 \mathrm{~K}$ на приборе Gemini VII 2390t Surface Area Analyzer. В приближении одинакового размера и шарообразной формы всех частиц по величине удельной поверхности $S_{\mathrm{sp}}$ оценивали средний размер частиц $D=6 / \rho S_{\mathrm{sp}}(\rho-$ плотность карбида).

Пикнометрическую плотность $\rho_{\mathrm{pHe}}$ исходных и размолотых карбидных порошков определяли с помощью гелиевого пикнометра АccuРус II 1340, используя измерительную камеру объемом $1 \mathrm{~cm}^{3}$. Перед измерением удельной поверхности и пикнометрической плотности порошки сушили в вакууме 10 Ра при температуре $573 \mathrm{~K}$ в течение $1 \mathrm{~h}$. Дополнительно плотность $\rho_{\mathrm{pl}}$ порошков карбида ниобия измеряли методом жидкостной пикнометрии [21,22] при температуре $298 \mathrm{~K}$. В качестве рабочей жидкости использовали очищенный керосин. Плотность $\rho_{\mathrm{pl}}$ рассчитывали по формуле

$$
\rho_{\mathrm{pl}}=\frac{m}{M_{0}-M_{p}+m}\left(\delta-\rho_{\mathrm{air}}\right)+\rho_{\mathrm{air}}
$$

где $m$ - масса исследуемого вещества; $M_{0}$ - масса пикнометра с керосином, доведенным до метки при температуре измерения; $M_{p}$ - масса пикнометра с исследуемым веществом и керосином; $\delta=0.7837 \mathrm{~g} \mathrm{~cm}^{-3}-$ плотность керосина при $298 \mathrm{~K} ; \rho_{\text {air }}=0.0012 \mathrm{~g} \mathrm{~cm}^{-3}-$ плотность воздуха при 298 К. При измерении плотности порошков $\mathrm{NbC}_{y}$ в керосине пикнометр с суспензией для удаления воздушных пузырьков в течение $3 \mathrm{~min}$ подвер- гали воздействию ультразвука в ванне Reltec ultrasonic bath USB-1/100-TH.

\section{3. Влияние размера частиц на измеряемую плотность нанопорошков}

Согласно дифракционным данным все исходные порошки карбидов $\mathrm{NbC}_{0.77}, \mathrm{NbC}_{0.84}, \mathrm{NbC}_{0.93}$ и $\mathrm{NbC}_{0.96}$ являются однофазными и имеют кубическую (пр.гр. $F m \overline{3} m)$ структуру типа $B 1$. Рентгеновская дифракция нанокристаллических порошков, полученных размолом в течение разного времени от 5 до $15 \mathrm{~h}$, обнаружила в них примесную фазу гексагонального карбида вольфрама WC в количестве до 3-4wt.\% в зависимости от продолжительности размола. Появление примеси WC обусловлено натиранием материала мелющих шаров и футеровки стаканов, изготовленных из твердого сплава WC -6 wt.\% Co.

Увеличение продолжительности размола сопровождается уширением дифракционных отражений, проиллюстрированным на примере карбида $\mathrm{NbC}_{0.77}$ (рис. 1). Анализ уширения дифракционных отражений показал, что уширение обусловлено как малым размером $D$ областей когерентного рассеяния (ОКР) в нанопорошках, так и наличием в них микронапряжений. Размер ОКР во всех изученных нанопорошках $\mathrm{NbC}_{y}$ приведен в таблице. Оценка размера $D$ частиц по величине удельной поверхности $S_{\mathrm{sp}}$ порошков (см. таблицу) в пределах ошибок эксперимента согласуется с размером ОКР. 


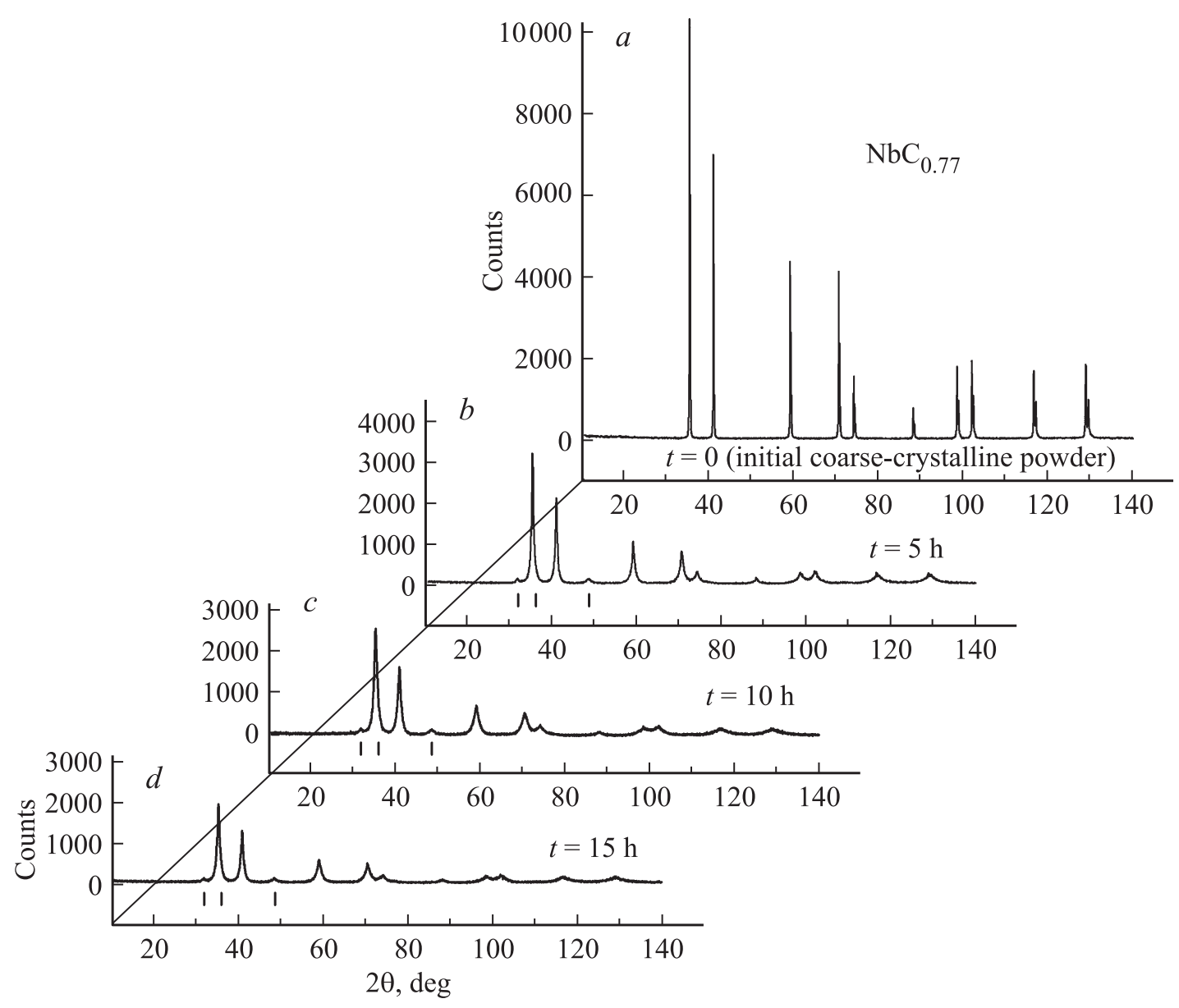

Рис. 1. Рентгенограммы исходного крупнокристаллического порошка карбида ниобия $\mathrm{NbC}_{0.77}$ и нанокристаллических порошков $\mathrm{NbC}_{0.77}$, полученных размолом крупнозернистого порошка в течение $5(b), 10(c)$ и $15 \mathrm{~h}(d)$. Штрихи на рентгенограммах нанопорошков соответствуют отражениям примесного карбида вольфрама WC.

На рис. 2 как пример показаны SEM изображения исходного крупнокристаллического и нанокристаллических порошков $\mathrm{NbC}_{0,84}$, полученных размолом в течение 5,10 и $15 \mathrm{~h}$. Размер частиц крупнокристаллического порошка составляет от 3 до $10 \mu \mathrm{m}$. В результате 5-часового размола наблюдаемый размер частиц уменьшился до 200-300 nm (рис. 2, b), но при большем увеличении видно, что эти частицы - агломераты частиц меньшего размера. Увеличение энергии размола до $\sim 28$ и $\sim 42 \mathrm{~kJ}(t=10$ и $15 \mathrm{~h}$ соответственно) привело к существенному измельчению порошка (рис. $2, c, d$ ).

Рентгеновскую плотность $\rho_{X}$ карбидов $\mathrm{NbC}_{y}$ определяли по формуле

$$
\rho_{X}=n M g / V
$$

где $n=4$ - число формульных единиц $\mathrm{NbC}_{y}$, приходящихся на элементарную ячейку карбида с кубической структурой $B 1 ; M-$ молекулярная масca; $g=1.66 \cdot 10^{-27} \mathrm{~kg}-$ атомная единица массы; $V=a_{B 1}^{3}$ - объем элементарной ячейки карбида $\mathrm{NbC}_{y}$ с периодом решетки $a_{B 1}$. Период решетки $a_{B 1}$ и рентгеновская плотность $\rho_{X}$ карбидов ниобия практически не зависят от продолжительности или энергии размола (см. таблицу). Плотности $\rho_{\mathrm{pHe}}$ и $\rho_{\mathrm{pl}}$, измеренные методами гелиевой и жидкостной пикнометрии, неплохо согласуются между собой, но заметно уменьшаются по мере размола порошков (рис. 3).

В нестехиометрических карбидах $\mathrm{MC}_{y}$ структурные вакансии содержатся только в углеродной (неметаллической) подрешетке, но в нестехиометрических кубических монооксидах титана, ванадия и ниобия $\mathrm{M}_{x} \mathrm{O}_{z}$ вакансии могут содержаться в кислородной и металлической подрешетках одновременно [7].

Сопоставление рентгеновской и пикнометрической плотностей крупнокристаллических (с размером частиц 3-5 $\mathrm{m}$ ) порошков нестехиометрических монооксидов с двойной дефектностью используется для определения степени заполнения узлов металлической и кислородной подрешеток атомами металла и кислорода соответственно [23-25]. В этом случае меньшая пикнометрическая плотность $\rho_{\mathrm{pHe}}$ (или $\rho_{\mathrm{pl}}$ ) по сравнению с рентгеновской плотностью $\rho_{X}$ является свидетельством присутствия структурных вакансий в металлической подрешетке. $\mathrm{B}$ монооксидах $\mathrm{M}_{x} \mathrm{O}_{z}$ степень заполнения атомами ме- 
$a$
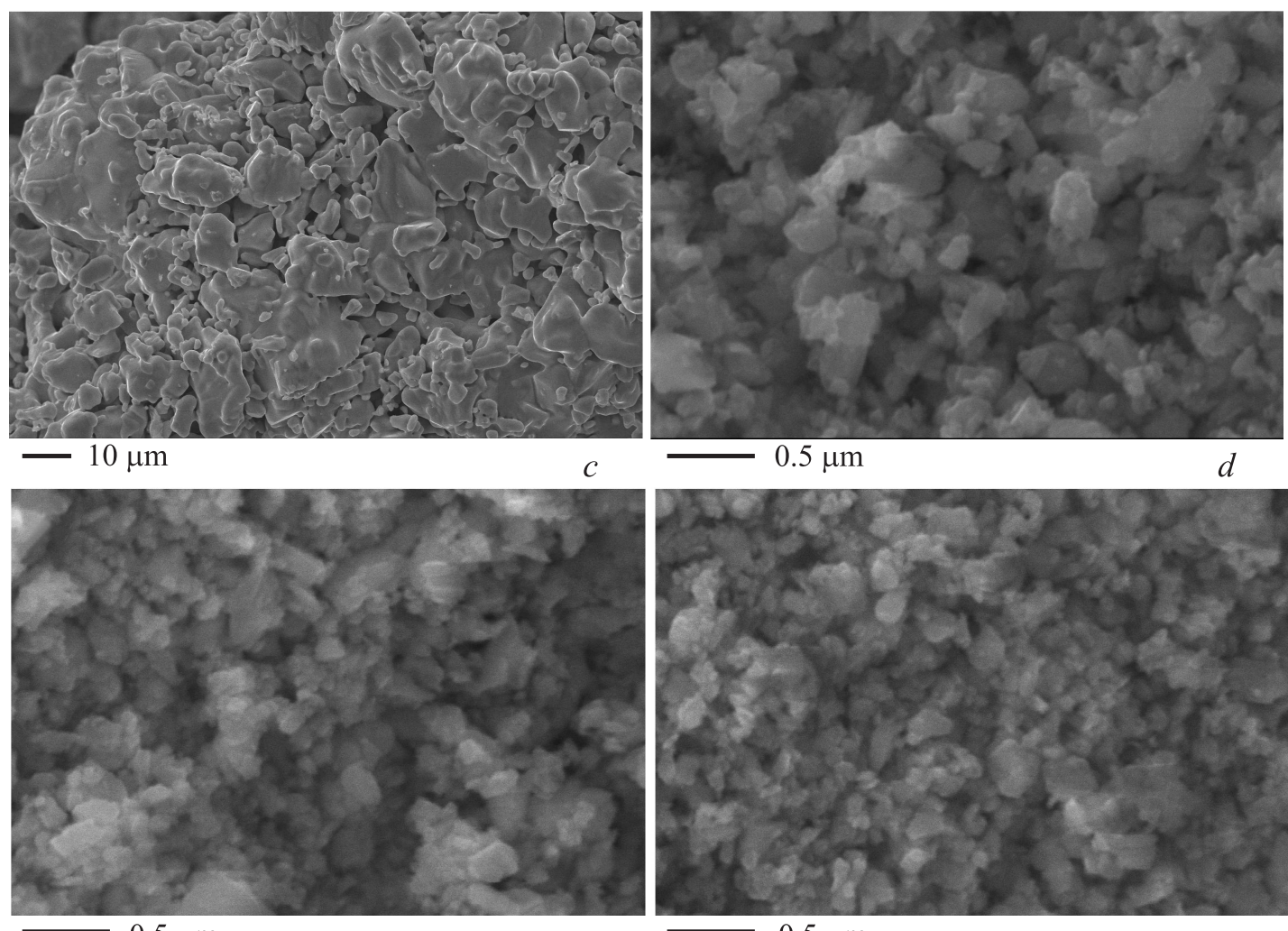

$0.5 \mu \mathrm{m}$

$0.5 \mu \mathrm{m}$

Рис. 2. Сканирующая электронная микроскопия порошков карбида $\mathrm{NbC}_{0.84}$ : $(a)$ исходный крупнокристаллический порошок содержит большие частицы размером от $\sim 3$ до $\sim 8 \mu \mathrm{m} ;(b),(c),(d)$ нанокристаллические порошки, полученные размолом исходного порошка в течение 5,10 и $15 \mathrm{~h}$ соответственно.

талла узлов металлической подрешетки определяется как $x=\rho_{p} V c_{\mathrm{M}} / n A_{\mathrm{M}} g$, где $c_{\mathrm{M}}$ и $A_{\mathrm{M}}$ - массовая доля металла в оксиде и атомная масса металла.

Нестехиометрические карбиды ниобия не обладают двойной дефектностью. Свидетельством этого является совпадение рентгеновской и пикнометрических плотностей исходных крупнокристаллических порошков (см. таблицу). Заметная разница плотностей $\rho_{X}$ и $\rho_{\mathrm{pHe}}$ (или $\rho_{\mathrm{pl}}$ ) наблюдается только для нанопорошков. Удельная поверхность крупнокристаллических порошков мала, поэтому поверхностная адсорбция газа или несмачивание поверхности порошка жидкостью пренебрежимо малы и практически не влияют на измеряемую пикнометрическую плотность. В случае нанокристаллических порошков удельная поверхность очень велика. В результате объем газа, адсорбированного поверхностью, или несмачиваемость поверхности жидкостью заметно влияют на измеренные объем образца и его пикнометрическую плотность. Объем завышается, а плотность занижается, что и наблюдается экспериментально.

Влияние площади удельной поверхности и поверхностной адсорбции газа на измеряемую плотность нанопорошков было рассмотрено ранее [26] на примере гелиевого пикнометра АccuРус 1340. Принцип действия гелиевого пикнометра показан на рис. 4. Пикнометр состоит из эталонной камеры объемом $V_{\text {et }}$ и измерительной камеры объемом $V_{\text {cell }}=1 \mathrm{~cm}^{3}$, в которую помещен образец исследуемого твердого вещества объемом $V_{s}$. Камеры соединены через клапан и оснащены датчиками давления. Первоначально эталонная камера заполняется гелием под повышенным давлением $P_{1}$, а измерительная камера заполняется гелием под атмосферным давлением $P_{\text {atm. }}$. Затем открывается клапан и давление газа в камерах выравнивается до величины $P_{2}$, причем $P_{1}>P_{2}>P_{\text {atm }}$.

В [26] показано, что объем $V_{s}$ крупнокристаллического вещества определяется как

$$
V_{s}=V_{\text {cell }}-V_{\text {et }}\left(\frac{P_{1}-P_{\mathrm{atm}}}{P_{2}-P_{\mathrm{atm}}}-1\right) .
$$

Формула (3) верна для крупнокристаллического порошка, когда удельная поверхность $S_{\mathrm{sp}}$ (площадь поверхности, отнесенная на единицу массы) невелика и поверхностная адсорбция гелия пренебрежимо мала. При известной массе $m$ исследуемого вещества конечный результат выдается как плотность $\rho_{s}=m / V_{s}$, которая соответствует истинной плотности крупнозернистого вещества (порошка) с частицами размером несколько микрометров и более. 


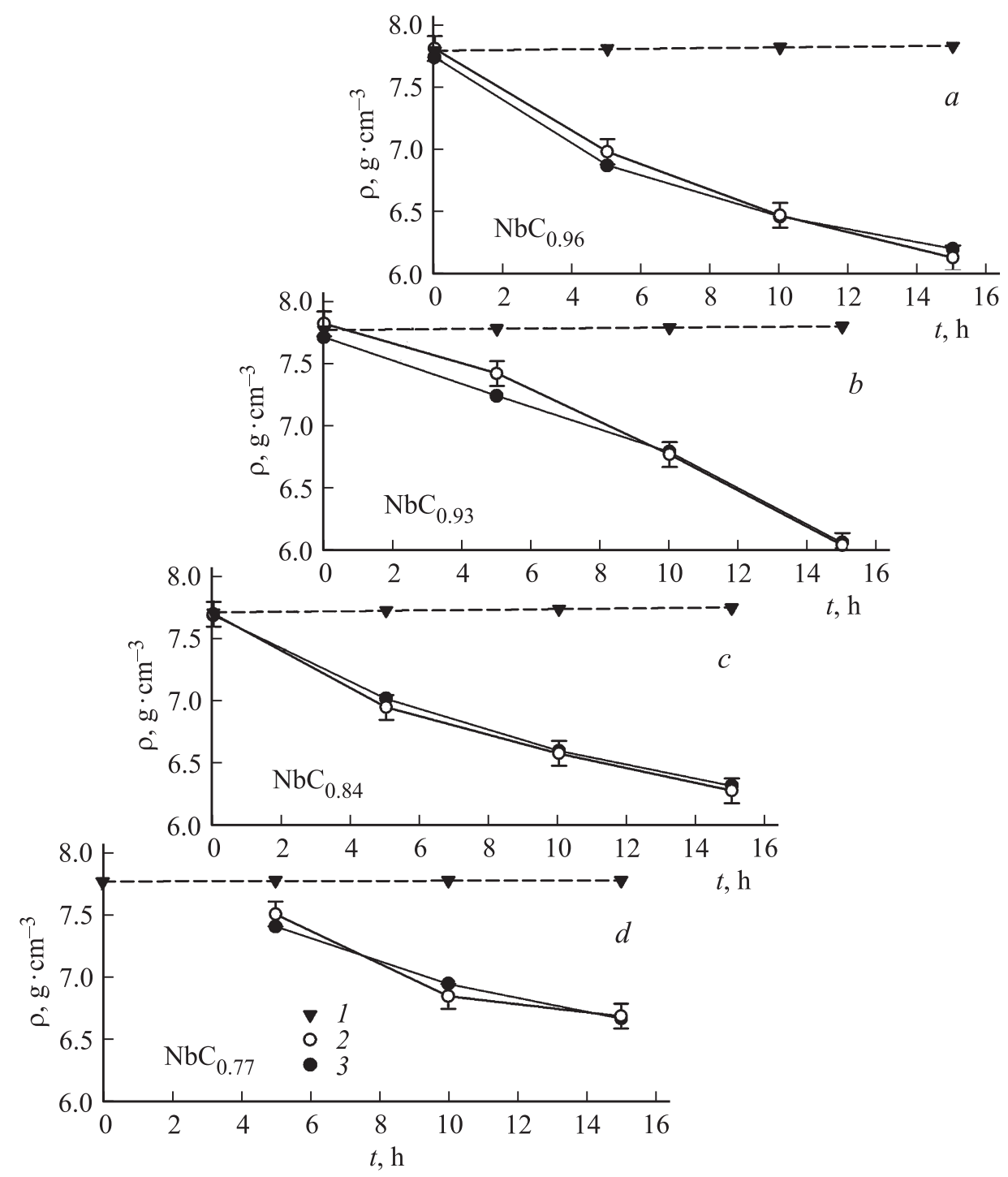

Рис. 3. Изменение пикнометрической плотности порошков карбида ниобия $\mathrm{NbC}_{y}$ с $y=0.96(a), 0.93(b), 0.84(c), 0.77(d)$ в зависимости от продолжительности $t$ размола: (1) рентгеновская плотность $\rho_{X}$; (2) и (3) плотности $\rho_{\mathrm{pl}}$ и $\rho_{\mathrm{pHe}}$, измеренные методами жидкостной и гелиевой пикнометрии соответственно.

Нанокристаллические порошки обладают очень большой удельной поверхностью. Благодаря высокоразвитой поверхности нанопорошки адсорбируют часть газа [27]. Вследствие адсорбции давление газа понижается, измеренный объем $V_{\text {s-nano }}$ оказывается завышенным, а плотность порошка заниженной.

Первоначально эталонная камера заполнена гелием под повышенным давлением $P_{1}$, и число молей $\mathrm{He}$ в ней равно $n_{\mathrm{et} 1}=P_{1} V_{\mathrm{et}} / R T$. В измерительной камере гелий находится под атмосферным давлением $P_{\mathrm{atm}}$. Если в начальный момент времени число молей газа, адсорбированного поверхностью нанопорошка, равно $\Delta n_{1}$, то в соответствии с уравнением Менделеева-Клапейрона $\Delta n_{1}=P_{\mathrm{atm}} \Delta V_{1} / R T$, а общее число молей гелия в измерительной камере равно $n_{c 1}=P_{\text {atm }}\left(V_{\text {cell }}-V_{\text {s-nano }}\right) / R T+\Delta n_{1}$. После выравнивания давления в камерах до величины $P_{2}$ и учета зависи- мости количества адсорбированного гелия от величины давления число молей $\mathrm{He}$ в измерительной и эталонной камерах равно $n_{c 2}=P_{2}\left(V_{\text {cell }}-V_{\text {s-nano }}\right) / R T+\Delta n_{2}$ и $n_{\mathrm{et} 2}=P_{2} V_{\mathrm{et}} / R T$ соответственно. Поскольку $P_{2}>P_{\mathrm{atm}}$, то $\Delta n_{2}>\Delta n_{1}$. Количество гелия в обеих камерах не изменилось, поэтому

$$
n_{\mathrm{et} 1}+n_{c 1}=n_{\mathrm{et} 2}+n_{c 2} .
$$

Подставляя вместо $n_{\mathrm{et} 1 \text {, et2 }}$ и $n_{c 1, c 2}$ их значения, выраженные через давления и объемы, получим

$$
\begin{aligned}
P_{1} V_{\text {et }}+P_{\text {atm }}\left(V_{\text {cell }}\right. & \left.-V_{\text {s-nano }}\right)+\Delta n_{1} R T=P_{2} V_{\text {et }} \\
& +P_{2}\left(V_{\text {cell }}-V_{\text {s-nano }}\right)+\Delta n_{2} R T
\end{aligned}
$$

или

$$
\begin{aligned}
\left(P_{2}-P_{\text {atom }}\right) V_{\text {s-nano }}= & \left(P_{2}-P_{\text {atm }}\right) V_{\text {cell }}-\left(P_{1}-P_{2}\right) V_{\text {et }} \\
& +\left(\Delta n_{2}-\Delta n_{1}\right) R T .
\end{aligned}
$$



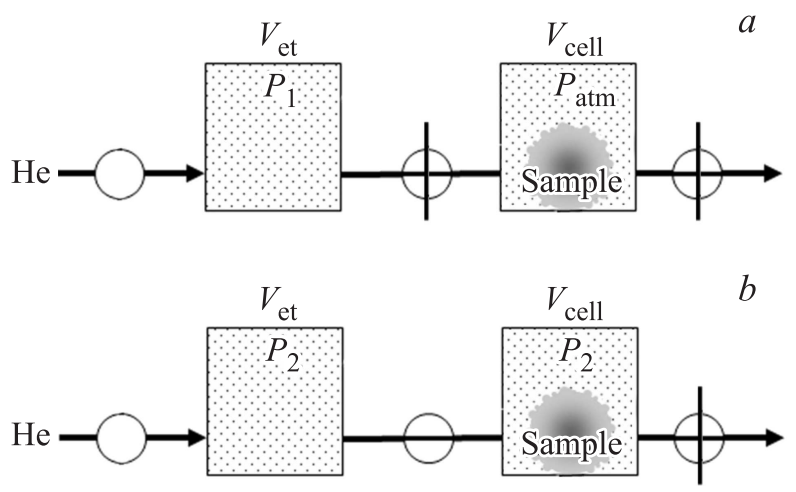

Рис. 4. Схема работы гелиевого пикномера с объемом измерительной камеры $V_{\text {cell }}=1 \mathrm{~cm}^{3}$. (a) первоначальное состояние перед измерением, $(b)$ состояние во время измерения, $V_{\text {et }}$ - объем эталонной камеры, $P_{1}>P_{2}>P_{\text {atm }}$ - давление гелия Не в камерах на разных этапах измерения.

Из (6) следует, что измеренный объем нанопорошка имеет вид

$$
V_{\text {s-nano }}=V_{\text {cell }}-V_{\text {et }}\left(\frac{P_{1}-P_{\mathrm{atm}}}{P_{2}-P_{\mathrm{atm}}}-1\right)+\frac{\left(\Delta n_{2}-\Delta n_{1}\right) R T}{P_{2}-P_{\mathrm{atm}}} .
$$

Из сравнения выражений (3) и (7) ясно, что изза адсорбции гелия поверхностью нанопорошка объем $V_{\text {s-nano }}$ завышен на величину $\Delta V=\left(\Delta n_{2}-\Delta n_{1}\right) R T$ / $\left(P_{2}-P_{\text {atm }}\right)>0$ по сравнению с реальным объемом нанопорошка. Измеренный объем $V_{\text {s-nano нанопорошка и }}$ его плотность $\rho_{\mathrm{s}-\mathrm{nano}}$ следует называть кажущимися, так как объем завышен, а плотность занижена (в технике объем и плотность порошков называют насыпными). Именно такая зависимость наблюдается для нанопорошков карбида ниобия - чем больше продолжительность размола и меньше средний размер частиц нанопорошка, тем меньше измеренная кажущаяся плотность (см. рис. 3). В жидкостной пикнометрии измеренный

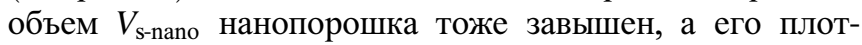
ность занижена из-за отсутствия полной смачиваемости поверхности наночастиц рабочей жидкостью.

В работе [26] показано, что разность $\Delta \rho$ истинной и измеренной плотностей равна

$$
\Delta \rho=\rho_{X}^{2} \frac{k R T}{c\left(3 \sqrt{3} r^{2} N_{\mathrm{A}}\right)\left(P_{2}-P_{\mathrm{atm}}\right)} S_{\mathrm{sp}}=A S_{\mathrm{sp}},
$$

где $r=0.031 \mathrm{~nm}$ - атомный радиус Не (ковалентный радиус гелия равен $0.028 \mathrm{~nm}), N_{\mathrm{A}}$ - число Авогадро, $S_{\mathrm{sp}}$ - площадь удельной поверхности порошка, $A$ и $c>1-$ постоянные. Поскольку $S_{\mathrm{sp}} \sim 1 / D$, то разность $\Delta \rho$ истинной и измеренной плотностей обратно пропорциональна среднему размеру $D$ наночастиц порошка, т. е.

$$
\Delta \rho=B / D,
$$

где $B-$ постоянная. Действительно, разность плотностей $\Delta \rho$ порошков карбида ниобия $\mathrm{NbC}_{y}$ практически линейно растет при увеличении площади удельной поверхности $S_{\mathrm{sp}}$ и увеличивается по зависимости гипербо- лического типа при уменьшении размера $D$ частиц (см. таблицу).

Заниженная плотность $\rho_{\mathrm{pl}}$ нанопорошков карбида ниобия $\mathrm{NbC}_{y}$, измеренная методом жидкостной пикнометрии, является следствием их супергидрофобности, объединяющей естественную гидрофобность и шероховатость, что приводит к почти полному несмачиванию поверхности [28-30]. Для описания супергидрофобных поверхностей нанопорошков используют модель КассиБакстера [31], когда полости текстуры поверхности заполнены газом и контакт жидкости с порошком представляет собой гетерогенную межфазную границу жидкость-твердое-газ. Коэффициент шероховатости определяется как отношение реальной площади поверхности к площади ее проекции на горизонтальную плоскость. Для сильно шероховатых поверхностей, что характерно для нанопорошков, равновесный краевой угол смачивания существенно больше краевого угла для плоских поверхностей того же вещества и достигает $150-180^{\circ}[28,29]$.

Большая разность истинной и измеренной пикнометрической плотностей нанопорошков карбида ниобия свидетельствует о их супергидрофобности и возможности применения как компонента защитных супергидрофобных покрытий.

\section{4. Заключение}

Измерения плотности крупно- и нанокристаллических порошков нестехиометрического кубического карбида ниобия $\mathrm{NbC}_{y}(0.77 \leq y \leq 0.96)$ с помощью гелиевой и жидкостной пикнометрии показали, что пикнометрическая плотность нанопорошков уменьшается при уменьшении среднего размера частиц и увеличении площади удельной поверхности нанопорошков. Совпадение пикнометрической и рентгеновской плотностей крупнокристаллических карбидных порошков указывает на отсутствие структурных вакансий в металлической подрешетке изученных карбидов ниобия. С учетом этого и большой удельной поверхности нанопорошков меньшая пикнометрическая плотность нанопорошков обусловлена адсорбцией части газа (в случае гелиевой пикнометрии). Вследствие этого измеренный объем нанопорошков оказывается завышенным, а плотность нанопорошков заниженной. Наблюдаемый эффект меньшей насыпной плотности карбидных нанопорошков следует учитывать при интерпретации результатов измерения плотности.

Авторы благодарят О.В. Макарову за помощь в измерении пикнометрической плотности порошков карбида ниобия.

\section{Список литературы}

[1] A.I. Gusev, A.A. Rempel. Nanocrystalline Materials. Cambridge Int. Sci. Publ., Cambridge (2004). 351 p.

[2] A.I. Gusev. In: Dekker Encyclopedia of Nanoscience and Nanotechnology / Eds J.A. Schwarz, C. Contescu, K. Putyera. Marcel Dekker Inc., N.Y. (2004). V. 3. P. 2289-2304. 
[3] А.А. Ремпель. Успехи химии 76, 5, 474 (2007).

[4] P. Baláž. Mechanochemistry in Nanoscience and Minerals Engineering. Springer, Berlin-Heidelberg (2008). 413 p.

[5] A.S. Kurlov, A.I. Gusev. Tungsten Carbides: Structure, Properties and Application in Hard-metals. Springer, ChamHeidelberg-N.Y.- Dordrecht-London (2013). 256 p.

[6] А.С. Курлов, А.И. Гусев. Физика и химия карбидов вольфрама. Физматлит, М. (2013). 272 с.

[7] A.I. Gusev, A.A. Rempel, A.J. Magerl. Disorder and Order in Strongly Nonstoichiometric Compounds: Transition Metal Carbides, Nitrides and Oxides. Springer, Berlin-HeidelbergN.Y.-London (2001). 607 p.

[8] A.S. Kurlov, A.I. Gusev. J. Alloys Comp. 582, 108 (2014).

[9] А.С. Курлов, И.А. Бобриков, А.М. Балагуров, А.И. Гусев. Письма в ЖЭТФ 100, 10, 712 (2014).

[10] A.S. Kurlov, A.I. Gusev. Int. J. Refr. Met. Hard. Mater. 46, 125 (2014).

[11] А.С. Курлов, А.И. Гусев. Неорган. материалы 51, 1, 34 (2015).

[12] A.M. Balagurov, I.A. Bobrikov, G.D. Bokuchava, R.N. Vasin, A.I. Gusev, A.S. Kurlov, M. Leoni. Mater. Charact. 109, 173 (2015).

[13] А.А. Ремпель, А.И. Гусев. ФТТ 42, 7, 1243 (2000).

[14] L.-M. Berger, M. Hermann, A.I. Gusev, A.A. Rempel. Offenlegungsshrift DE 19807589 A 1. Int. Cl.6: C 01 B 31/30 (C 04 B 35/36). Bundesrepublik Deutschland: Deutsches Patentamt: Anmeldetag 23.02.1998, Offenlegungstag 10.09.1998. P. 1-3.

[15] A.I. Gusev, A.S. Kurlov. Nanotechnology 19, 26, 265302 (2008).

[16] А.С. Курлов, А.И. Гусев. ЖТФ 81, 7, 76 (2011).

[17] A.I. Gusev, A.S. Kurlov, T.D. Bel'kova, A.M. Bel'kov. Int. J. Refr. Met. Hard. Mater. 51, 70 (2015).

[18] А.И. Гусев, А.С. Курлов, А.М. Бельков, Т.Д. Белькова. ФТТ 57, 6, 1149 (2015).

[19] X'Pert Plus Version 1.0. Program for Crystallography and Rietveld analysis Philips Analytical B.V. Koninklijke Philips Electronics N. V.

[20] A.S. Kurlov, A.I. Gusev. Phys. Rev. B 76, 17, 174115 (2007).

[21] Э.М. Бондштедт-Куплетская. Определение удельного веса минералов. Изд-во АН СССР, М. (1951). 128 с.

[22] С.И. Гаузнер, С.С. Кивилис, А.П. Осокина, А.М. Павловский. Измерение массы, объема и плотности. Изд-во стандартов, М. (1972). 623 с.

[23] S. Andersson, B. Collen, U. Kuylenstierna, A. Magneli. Acta Chem. Scand. 11, 10, 1641 (1957).

[24] M.D. Banus, T.B. Reed. In: The Chemistry of Extended Defects in Non-Metallic Solids / Eds L. Eyring, M.O. Keeffe. North-Holland Publ., Amsterdam-London (1970). P. 488521.

[25] А.А. Валеева, А.А. Ремпель, А.И. Гусев. Письма в ЖЭТФ 71, 11, 675 (2000).

[26] А.С. Курлов, А.И. Гусев. ФТТ 58, 8, 1629 (2016).

[27] А.П. Карнаухов. Адсорбция. Текстура дисперсных и пористых материалов. Наука, Новосибирск (1999). 470 с.

[28] C.-H. Choi, U. Ulmanella, J. Kim, C.M. Ho, C.-J. Kim. Phys. Fluids 18, 8, 087105 (2006).

[29] A.M.J. Davis, E. Lauga. J. Fluid Mech. 661, 402 (2010).

[30] E. Bormashenko, R. Grynyov, G. Chaniel, H. Taitelbaum, Y. Bormashenko. App. Surf. Sci. 270, 98 (2013).

[31] A.B.D. Cassie, S. Baxter. Nature 155, 3923, 21 (1945). 